\title{
A Bibliometric Profile of the Tourism-Economics Sub-Field in Turkish Academic Community
}

\author{
Yakup Kemal ÖZEKICI iD a \\ a Adiyaman University, Tourism faculty, Adiyaman, Turkey. ykozekici@gmail.com
}

\begin{tabular}{|c|c|}
\hline ARTICLE INFO & ABSTRACT \\
\hline \multirow{3}{*}{$\begin{array}{l}\text { Keywords: } \\
\text { Bibliometric analysis } \\
\text { Literature review } \\
\text { Tourism economics } \\
\text { Tourism academic } \\
\text { community }\end{array}$} & Purpose - The aim of the study is to reveal the main characteristics of the domestic tourism-economics \\
\hline & $\begin{array}{l}\text { literature, as well as to compare the contributions made by the tourism, economics and administrative } \\
\text { science (EAS) academia. The purpose is to identify the most distinctive aspects, more specifically, } \\
\text { subjects (subdivision of economics, main topics, subtopics), methods (study design and sub design) and } \\
\text { citations within the literature. }\end{array}$ \\
\hline & $\begin{array}{l}\text { Design/methodology/approach - To fulfil this aim, } 291 \text { articles in peer-reviewed journals published } \\
\text { between } 2000 \text { and } 2019 \text { were compiled, encoded, categorized and analysed based on semi-systematic } \\
\text { literature review principles. }\end{array}$ \\
\hline Received 23 December 2020 & Findings - It is concluded that studies on the macroeconomic context are ahead of the microeconomic \\
\hline Revised 25 February 2021 & context, and that the role of tourism on economic growth is the mostly studied and cited subject. \\
\hline Accepted 25 March 2021 & Furthermore, these studies are dominantly carried out by authors from the department of EAS. \\
\hline \multirow[t]{2}{*}{$\begin{array}{l}\text { Article Classification: } \\
\text { Research Article }\end{array}$} & $\begin{array}{l}\text { Similarly, quantitatively designed studies have three times more representation than qualitatively and } \\
\text { conceptually designed studies. Within that, causality analysis, panel data and multiple approaches are } \\
\text { generally adopted for quantitative studies, while tables are chosen as the leading method within } \\
\text { qualitative ones. }\end{array}$ \\
\hline & $\begin{array}{l}\text { n - All these findings imply that studies macroeconomics, conceptually designed and carried } \\
\text { thors from EAS are more likely to be cited. }\end{array}$ \\
\hline
\end{tabular}

\section{INTRODUCTION}

Tourism phenomenon reflects a multidisciplinary identity across numerous disciplines (Tribe, 1997). Among them, economy discipline has an archaic, specific and pioneering role as a consolidated theoretical base with its contributing academic community to tourism field (Canosa et al., 2018; Tribe \& Liburd, 2016; Weiler et al., 2012). Also, despite having a fading prevalence from the onset of interdisciplinary knowledge construction of tourism domain (Oviedo-García, 2016; Weiler et al., 2012), tourism economics studies have been pursuing its significance both in quality and quantity (Huang, 2011; Ma \& Law, 2009). To that end, the role of the economy discipline in the tourism field has been addressed on the global scale and bibliography-oriented studies in this respect have been undertaken to compile and evaluate the extant literature (Comerio \& Strozzi, 2019; Li et al., 2005; Mohammed et al., 2015). Yet, the holistic contributions of the foremost disciplines to the tourism field in the context of knowledge production have not been addressed in detail (Tribe \& Liburd, 2016). This is because the body of knowledge reflecting the tourism literature is not internationally oriented and domestic publications constitute a remarkable part of this body of knowledge. This is the case especially for countries whose financial structure depends, partly or significantly, on the tourism revenue due to its remedial benefits ranging from closing current account deficit (Bozgeyik \& Kutlu, 2019; Ünlüönen \& Özekici, 2018) to enabling economic growth (Bozgeyik \& Yoloğlu, 2015). Turkey stands as one of those countries as academic output of its tourism academic community falls under the department of economics and administrative sciences (EAS) until the last decade (Gülcan, 2009; Kozak, 2001). However, many bibliometric studies have provided deeper insights on general (Tayfun et al., 2016; I. Y1lmaz, 2019) and various sub-literatures within domestic tourism field (Arıca, 2014; Arıkan-Saltık, 2020; Aydın, 2017; Bayın, 2015; Baytok et al., 2019; Boğan et al., 2018; Bozok et al., 2017; Çapar et al., 2018; Düşmezkalender \& Metin, 2019; Işık et al., 2019; Kervankıran et al., 2019; Kozak, 2001; Özel \& Kozak, 2012; Şahin \& Acun, 2015; Saltık \& Alimanoğlu, 2018; Sökmen \& Özkanl1, 2018; Temizkan et al., 2015; Yeşilyurt \& Koçak, 2018; Y1lmaz, 2017b) in Turkey (Yılmaz, 2019); yet, to our knowledge, there is 
no study explicating the structure of the existing knowledge on tourism economics within the domestic literature for this country. More specifically, despite its prominence, there remains a lack of understanding which subjects have remained unstudied, which study design and sub design as methods are not examined sufficiently, and which academic community has contributed to this sub-literature in what extent in the context of tourism economics literature. Finally, no study has examined the criteria according to which the studies regarding tourism economics are cited. The literature review methods are useful when aiming to map the state of a given field over time, and to reveal the gaps within it(Snyder, 2019, p. 333); these methods have been accepted as an important tool to determine the progress a research area has gained (Wu et al., 2012). Therefore, it is the aim of this study to reveal the structure of the knowledge available in the scope of tourism and economics nexus from 2000 to 2019. Additionally, it reveals the role of tourism and non-tourism researchers within the tourism economics literature by considering and comparing two communities (tourism and EAS) in terms of method, subject, design, and abundance of reference and citations. In detail, the aim is to shed light on whether particular factors such as the study period, the main theme of study and disciplinary origin of author(s) determine the citations gained. In this way, an overview is provided on the present status of the tourism-economic nexus and gaps and key areas revealed within the interdisciplinary connection between tourism and economic fields. By doing so, this study contributes to the literature in a way that lays the foundations for future researches with interdisciplinary perspectives to advance systematic knowledge production in the domestic literature.

\section{LITERATURE REVIEW}

\section{Tourism Economy as a Research Field}

Tourism economy as a research field is described as "...both conceptual and empirical studies in hospitality and tourism journals that relate to any segment of the hospitality industry (hotel/lodging/accommodation/resort, restaurant/food and beverage services, casino/gaming/gambling, assisted living facilities, institutional food service, clubs, events, time share and so on), which dwells on theories, concepts, and/or methodologies from mainstream economics." (Mohammed et al., 2015, p. 100).

Economy has been regarded as being among the paramount disciplines within tourism (Jafari \& Aaser, 1988; Jafari \& Ritchie, 1981; Weiler et al., 2012), which is believed to be overwhelmed by business knowledge domain, therefore, the initial definitions in tourism phenomenon were affected by monetary aspects of the activities (Tribe, 1997). On the other hand, economy has dominated the way tourism knowledge is produced since the 1900s when the first tourism studies emerged (Butler, 2015; Gülcan, 2009). In the following decades, the tourism academic community directed its efforts to the economic impact of its activities during its period of blossoming as a research area in the 1960s (Canosa et al., 2018; Weiler et al., 2012), when the contributions of tourism to economies were first discussed (Jafari \& Ritchie, 1981). This period coincides with the flourishing of tourism economics studies (Li et al., 2005), which became more dominant in the 1980s and 1990s (Ren et al., 2010) and continued until the 2000s (Botterill et al., 2002; Cheng et al., 2011). At this point, the maturity of tourism studies was believed to have been conceived (Wu et al., 2012). Yet, In the years that followed, the gradually decreasing impact of economy on tourism was observed by Meyer-Arendt \& Justice (2002). Since then, the role of economy in tourism research was seen to decline and rank fifth (Darbellay \& Stock, 2012) or fourth (Wu et al., 2012) after psychology, anthropology, sociology, ecology and history.

Such dominance is still accepted, especially in the context of some regional tourism academic communities (Huang, 2011; Ma \& Law, 2009), However, a globally declining emphasis on this discipline has been witnessed over the years (Meyer-Arendt \& Justice, 2002; Weiler et al., 2012). The gradually waning prominence of tourism economic studies is attributed to the emergence of other disciplines such as sociology, anthropology and ecology (Canosa et al., 2018; Jafari, 2003) as an integrated knowledge apparatus with tourism phenomenon. The diminishing role of economy in tourism is also related to the potential effect of tourism believed to have side effects other than its financial aspect (Franklin \& Crang, 2001). In other words, remarkable environmental and cultural impacts resulting from the tourist activities were observed which, in turn, were reflected in the output of tourism academic communities as research (Carr \& Hayes, 2017). Accordingly, other disciplines were integrated within the tourism academic network by embedding their theories and methods in tourism (Laws \& Scott, 2015). This period is described as the second evolutionary step of tourism knowledge platform called the "cautionary platform" (Jafari, 2003), which enabled indisciplinarity of tourism knowledge platform 
(Tribe, 1997) to emerge and other rigorous discipline to approach tourism field from a structural aspect (Jovicic, 1988). Likewise, the interest of these disciplines in tourism field stemmed from the reciprocal relations within tourism system at the destination scale (Laws \& Scott, 2015). Thus, the potential effect of any explicit factor on destination is seen to result in interdisciplinary relations between a discipline and tourism research field. This was the case with economy discipline in particular; in this context, the tourism-economy intersection within both phenomenological and knowledge platforms has revealed sub-themes known as tourism economics (Mohammed et al., 2015; Tribe, 1997). This intersection was grouped into two major topics as micro and macroeconomics by Mohammed et al. (2015), as exhibited in Table 1 showing the boundaries of tourism economics as a sub-field of tourism research platform.

Table 1: Output of intersection between tourism field and economy discipline

\begin{tabular}{|c|c|c|}
\hline Subdivision of Economics & Main Topic & Subtopics \\
\hline \multirow[t]{13}{*}{ Microeconomics } & \multirow[t]{5}{*}{ Market analysis } & Demand and its determinants \\
\hline & & Supply and its determinants \\
\hline & & Price determination and pricing \\
\hline & & Elasticities and their applications \\
\hline & & Demand and supply forecasting \\
\hline & \multirow[t]{2}{*}{ Consumer behaviour } & Consumer choice-making \\
\hline & & Expenditure shares \\
\hline & \multirow[t]{3}{*}{ Firm behaviour } & Production decisions \\
\hline & & Cost structures \\
\hline & & Revenue optimisation \\
\hline & \multirow[t]{3}{*}{ Industry analysis } & Market structure \\
\hline & & Conduct/firm behaviour \\
\hline & & Performance \\
\hline \multirow[t]{11}{*}{ Macroeconomics } & \multirow{7}{*}{$\begin{array}{c}\text { Interaction with } \\
\text { macroeconomic variable }\end{array}$} & The industry and economic growth \\
\hline & & The industry and inflation \\
\hline & & The industry and exchange rate \\
\hline & & The industry and unemployment \\
\hline & & The industry and interest rate \\
\hline & & The industry and capital flows \\
\hline & & Public policy and hospitality \\
\hline & \multirow{4}{*}{$\begin{array}{l}\text { Government policy and } \\
\text { hospitality industry }\end{array}$} & Fiscal policy and hospitality \\
\hline & & Monetary policy and hospitality industry \\
\hline & & Impact/Multiplier studies \\
\hline & & Regional policy and hospitality \\
\hline
\end{tabular}

Source: (Mohammed et al., 2015)

Considering the position of economy discipline, it can be stated that it represents a fundamental platform for tourism through transforming its theories, methods and traditions. Therefore, a significant interrelation between these fields is accepted (Butler, 2015), the main argument being that understanding business-oriented behaviours of stakeholders in destinations plays an key role (Tribe \& Liburd, 2016). As a result, business studies - more specifically, economy discipline coupled with marketing and management fields are of utmost importance in tourism.

As for the scope of tourism academic community within Turkey, domestic tourism economics was the most researched sub-field until 2000s (İçöz \& Kozak, 1999). However, being parallel with the mainstream tourism literature, a gradual decline was observed in this sub-literature. Related studies ranked third (Evren \& Kozak, 2014; Tayfun et al., 2016) and farther behind (Aydın, 2017) management and marketing in tourism.

\section{Bibliographic Studies within the Turkish Academic Community}

A literature review can be described as a taxonomical way of constructing an extant literature on a particular issue (Tranfield et al., 2003). The accelerating rate of knowledge production rendered literature review 
methodologies more relevant than ever (Snyder, 2019). Obviously, the proliferation of these kinds of studies has repercussions within academic community in Turkey and elsewhere, and publication of studies whose main purpose is compiling and reviewing extant literature has gained momentum since 2016. Since then, a substantial number of similar studies have been published (Yilmaz, 2019).

Most bibliometric studies are not restricted to any specific sub-field within the tourism literature, and address all tourism-related research (e.g. Tayfun et al., 2016). These studies have generally chosen their main parameters as publication period, title of authors, disciplinary basis, and reference as the criteria upon which the study design was constructed. On the other hand, studies assorting and examining a specific sub-field within the tourism literature were rarely substantiated (Kozak, 2001). Yet, as previously stated, the increasing interest in other fields and disciplines other than management/economic areas within the tourism academic community has led to the emergence of different sub-fields within tourism field (Tribe, 1997; Tribe \& Liburd, 2016). As a result, the developing body of knowledge inside tourism academic community necessitates compiling various outputs towards these emerging subfields, both for the international and domestic academic community; however, except for diversified literature reviews or bibliometric studies covering international publications in management (e.g. Özekici \& Ünlüönen, 2019), even mature disciplines such as economics in the Turkish context remain unknown. The exceptions in this respect are those compiling studies related to marketing (Özel \& Kozak, 2012), geography (Kervankıran et al., 2019) and organizational behaviour (Saltık \& Alimanoğlu, 2018). Existing studies which covers a specific section of entire domestic tourism literature were compiled in table 2. 
Table 2: Literature review studies within the extent of sub-tourism subject

\begin{tabular}{|c|c|c|c|c|c|}
\hline Study & Period & Subject & Data Set & Parameters & Relevant Findings \\
\hline Arica (2014) & $1988-2013$ & $\begin{array}{l}\text { Dissertations on } \\
\text { travel agency }\end{array}$ & $\begin{array}{l}220 \\
\text { dissertations }\end{array}$ & $\begin{array}{l}\text { Publication date, research } \\
\text { subject, institute, } \\
\text { department, total pages, } \\
\text { methodology, sample size } \\
\text { and place of the sample }\end{array}$ & $\begin{array}{l}\text { Period covering 2007-2011 years reveals the most } \\
\text { dissertations at frequency. } \\
\text { Marketing field was the top study area for } \\
\text { dissertations at tourism field. } \\
\text { Istanbul University involves the utmost frequency } \\
\text { for dissertations. } \\
\text { - Quantitative study design was mostly preferred. }\end{array}$ \\
\hline Aydın (2017) & $1988-2013$ & $\begin{array}{l}\text { Dissertations on food } \\
\text { and beverage } \\
\text { management }\end{array}$ & $\begin{array}{l}179 \\
\text { dissertations }\end{array}$ & $\begin{array}{l}\text { Publication date, } \\
\text { department, instute, } \\
\text { university, subject, } \\
\text { department of advisory, } \\
\text { research type, } \\
\text { methodology, place of the } \\
\text { sample }\end{array}$ & $\begin{array}{l}\text { - Last period involves the most publications. } \\
\text { - } \text { Gazi University leads the literature on the subject. } \\
\text { ranked fourth place. } \\
\text { - Quantitative design ranked first as the most } \\
\text { preferred study method. }\end{array}$ \\
\hline Bayın (2015) & 1988-2014 & $\begin{array}{l}\text { Dissertations on } \\
\text { health tourism in } \\
\text { Turkey }\end{array}$ & $\begin{array}{l}95 \\
\text { dissertations }\end{array}$ & $\begin{array}{l}\text { Publication date, language } \\
\text { of the main text, } \\
\text { dissertation degree, } \\
\text { university, study design, } \\
\text { place of the sample }\end{array}$ & $\begin{array}{l}\text { - Master thesis contains the highest volume. } \\
\text { dissertations. } \\
\text { Most dissertations were written by authors from } \\
\text { management field. } \\
\text { - Study framework was mostly designed under the } \\
\text { premises of marketing field. }\end{array}$ \\
\hline $\begin{array}{l}\text { Baytok et al. } \\
\text { (2019) }\end{array}$ & 2009-2017 & $\begin{array}{l}\text { Conference papers } \\
\text { on ethics and social } \\
\text { responsibility }\end{array}$ & $\begin{array}{l}16 \\
\text { conference } \\
\text { papers }\end{array}$ & $\begin{array}{l}\text { Author diversity, } \\
\text { university, author title, } \\
\text { sample location }\end{array}$ & $\begin{array}{l}\text { Quantitatively and qualitatively designed studies } \\
\text { delineate a balanced distribution. } \\
\text { Issues such as sample designs, author titles and } \\
\text { university at which conference was held shows an } \\
\text { balanced equilibrium. }\end{array}$ \\
\hline $\begin{array}{l}\text { Bozok et al. } \\
(2017)\end{array}$ & 1996-2015 & $\begin{array}{l}\text { Studies on rural } \\
\text { tourism }\end{array}$ & $\begin{array}{l}\text { Over } 400 \\
\text { studies }\end{array}$ & Publication date & $\begin{array}{l}\text { - Last period contains the highest volume in the } \\
\text { context of study frequency. }\end{array}$ \\
\hline
\end{tabular}




\begin{tabular}{|c|c|c|c|c|c|}
\hline & & & $\begin{array}{l}\text { including } \\
\text { dissertations, } \\
\text { books, book } \\
\text { chapters and } \\
\text { conference } \\
\text { papers }\end{array}$ & & \\
\hline $\begin{array}{l}\text { Boğan et al. } \\
(2018)\end{array}$ & 2002-2017 & $\begin{array}{l}\text { Studies on corporate } \\
\text { social responsibility }\end{array}$ & $\begin{array}{l}23 \text { articles, } 31 \\
\text { conference } \\
\text { papers, } 15 \\
\text { dissertations }\end{array}$ & $\begin{array}{l}\text { Publication date, type of } \\
\text { the study, number of } \\
\text { authors, university, } \\
\text { sample type }\end{array}$ & $\begin{array}{l}\text { Quantitative study design is more preferred than } \\
\text { others. } \\
\text { There is almost no increase in the number of studies } \\
\text { according to the publication date. } \\
\text { - Various universities have a similar share of the } \\
\text { number of studies. }\end{array}$ \\
\hline $\begin{array}{l}\text { Çapar et al. } \\
(2018)\end{array}$ & 2005-2017 & $\begin{array}{l}\text { Studies on tourist } \\
\text { guide published in } \\
\text { Turkey }\end{array}$ & $\begin{array}{l}40 \\
\text { dissertations, } \\
103 \text { articles, } \\
41 \\
\text { conference } \\
\text { papers }\end{array}$ & $\begin{array}{l}\text { Publication date, } \\
\text { university, subject, } \\
\text { location as the publication } \\
\text { source, journals }\end{array}$ & $\begin{array}{l}\text { Balıkesir University ranks as the leading university } \\
\text { for publication frequency. } \\
\text { Tourist role, education, service and occupation are } \\
\text { the mostly studied subjects. } \\
\text { Last period contains the highest volume in context of } \\
\text { study frequency. }\end{array}$ \\
\hline $\begin{array}{l}\text { Düşmezkalender } \\
\text { \& Metin (2019) }\end{array}$ & $2000-2018$ & $\begin{array}{l}\text { Studies on } \\
\text { alternative tourism }\end{array}$ & 60 articles & $\begin{array}{l}\text { Publication date, reference } \\
\text { list numerosity, university, }\end{array}$ & $\begin{array}{l}\text { - Conceptual studies have the most representation. } \\
\text { than international publications. } \\
\text { - Alternative tourism potentials are the most } \\
\text { addressed study subject. }\end{array}$ \\
\hline Işık et al. (2019) & 1988-2019 & $\begin{array}{l}\text { Studies on tourism } \\
\text { and } \\
\text { entrepreneurship } \\
\text { literature }\end{array}$ & $\begin{array}{l}96 \text { paper } \\
\text { comprising } \\
\text { of conference } \\
\text { types, } \\
\text { articles, } \\
\text { dissertations }\end{array}$ & $\begin{array}{l}\text { Publication date, subjects, } \\
\text { sample type, methodology }\end{array}$ & $\begin{array}{l}\text { - Last period contains the highest volume in the } \\
\text { context of study frequency. } \\
\text { Entrepreneurship tendency as the subject was } \\
\text { mostly examined compared to the other study } \\
\text { subjects. } \\
\text { - Samples of the literature consist mainly from the } \\
\text { undergraduate students at the tourism department. } \\
\text { Quantitative study design has the maximum } \\
\text { representation rate in the literature. }\end{array}$ \\
\hline
\end{tabular}




\begin{tabular}{|c|c|c|c|c|c|}
\hline $\begin{array}{l}\text { Kervankiran et } \\
\text { al (2019) }\end{array}$ & $1975-2015$ & $\begin{array}{l}\text { Tourism geography } \\
\text { researches in Turkey }\end{array}$ & $\begin{array}{l}103 \\
\text { dissertations }\end{array}$ & $\begin{array}{l}\text { Citation geography, } \\
\text { Degree of dissertations, } \\
\text { university }\end{array}$ & $\begin{array}{l}\text { - Studies frequently cite other fields than tourism } \\
\text { geography sub-fields. } \\
\text { - International studies were not cited as much as } \\
\text { domestic studies. } \\
\text { - Master theses leads the literature. } \\
\text { - Most researches were produced by Istanbul } \\
\text { University. }\end{array}$ \\
\hline Kozak (2001) & $1972-1998$ & $\begin{array}{l}\text { Tourism marketing } \\
\text { dissertations } \\
\text { published within } \\
\text { Turkey }\end{array}$ & $\begin{array}{l}131 \\
\text { dissertations }\end{array}$ & $\begin{array}{l}\text { Publication date, main } \\
\text { branch, university, subject, } \\
\text { sub-subject within tourism } \\
\text { knowledge (5) }\end{array}$ & $\begin{array}{l}\text { - Studies are published dominantly on the master } \\
\text { degree. } \\
\text { - İstanbul and Gazi Universities leads in the frequency } \\
\text { of dissertations. } \\
\text { - Hotel branches were mostly preferred to study since } \\
1986 .\end{array}$ \\
\hline $\begin{array}{l}\text { Özel ve Kozak } \\
\text { (2012) }\end{array}$ & $2000-2010$ & $\begin{array}{l}\text { Tourism marketing } \\
\text { studies published } \\
\text { within Turkey }\end{array}$ & 286 articles & $\begin{array}{l}\text { Publication date, author } \\
\text { number, journal, total } \\
\text { pages, research } \\
\text { methodology, citation } \\
\text { count and type }\end{array}$ & $\begin{array}{l}\text { Journal articles are the mostly preferred academic } \\
\text { publication. } \\
\text { - Sources written in a foreign language are more } \\
\text { widely cited compared to domestic publications. }\end{array}$ \\
\hline $\begin{array}{l}\text { Saltık \& } \\
\text { Alimanoğlu } \\
\text { (2018) }\end{array}$ & 1995-2017 & $\begin{array}{l}\text { Organizational } \\
\text { behaviour studies in } \\
\text { tourism }\end{array}$ & $\begin{array}{l}166 \\
\text { dissertations }\end{array}$ & $\begin{array}{l}\text { Publication date, } \\
\text { university, subdesign }\end{array}$ & $\begin{array}{l}\text { - Last period contains the highest volume in the } \\
\text { context of study frequency. } \\
\text { - Quantitative study design is more preferred than } \\
\text { others. } \\
\text { - Master thesis contains the highest volume }\end{array}$ \\
\hline Saltık (2020) & $1989-2018$ & Tourist guide studies & $\begin{array}{l}94 \\
\text { dissertations }\end{array}$ & $\begin{array}{l}\text { Dissertation degree, } \\
\text { publication period, } \\
\text { university and }\end{array}$ & $\begin{array}{l}\text { - Quantitative study design is more preferred than } \\
\text { others. }\end{array}$ \\
\hline
\end{tabular}




\begin{tabular}{|c|c|c|c|c|c|}
\hline & & & & $\begin{array}{l}\text { department, subdesign, } \\
\text { data acquisition technique, } \\
\text { sample type }\end{array}$ & $\begin{array}{l}\text { Questionnaire forms are the mostly utilized data } \\
\text { acquisition technique. } \\
\text { Last period contains the highest volume in the } \\
\text { context of study frequency. }\end{array}$ \\
\hline $\begin{array}{l}\text { Sökmen \& } \\
\text { Özkanlı (2018) }\end{array}$ & 2013-2018 & Gastronomy studies & 281 articles & $\begin{array}{l}\text { Reference types, } \\
\text { publication date, } \\
\text { methodology, }\end{array}$ & $\begin{array}{l}\text { - Average number of studies in reference list is } 37 . \\
\text { - } \quad \text { Qualitative study design is slightly more utilized } \\
\text { than quantitative study design. } \\
\text { - Gazi University leads in publication frequency. }\end{array}$ \\
\hline $\begin{array}{l}\text { Şahin \& Acun } \\
\text { (2015) }\end{array}$ & 1990-2015 & Tourist guide studies & $\begin{array}{l}22 \\
\text { conference } \\
\text { papers }\end{array}$ & $\begin{array}{l}\text { University, title of author, } \\
\text { page numeroristy, subject, } \\
\text { reference list numerosity, } \\
\text { subject, citation geography }\end{array}$ & $\begin{array}{l}\text { Balanced numerosity is determined in terms of } \\
\text { geography of studies within reference lists. } \\
\text { Balikesir University rank as the leading university } \\
\text { for publication frequency. } \\
\text { Exploratory and descriptive studies have come into } \\
\text { prominence. } \\
\text { Questionnaires were preferred as the primary data } \\
\text { acquisition tool. }\end{array}$ \\
\hline $\begin{array}{l}\text { Yeşilyurt \& } \\
\text { Koçak (2018) }\end{array}$ & 1993-2018 & $\begin{array}{l}\text { Studies on support } \\
\text { of local communities } \\
\text { for tourism } \\
\text { development }\end{array}$ & 146 studies & $\begin{array}{l}\text { Publication date, subject, } \\
\text { sample method and } \\
\text { location }\end{array}$ & $\begin{array}{l}\text { Quantitative design ranked first place as the most } \\
\text { preferred study method. } \\
\text { Total page number generally delimited between 11- } \\
20 .\end{array}$ \\
\hline Y1lmaz (2017) & 2009-2015 & $\begin{array}{l}\text { Gastronomy studies } \\
\text { published in } \\
\text { congresses }\end{array}$ & $\begin{array}{l}63 \\
\text { conference } \\
\text { papers }\end{array}$ & $\begin{array}{l}\text { Publication date, average } \\
\text { page number, average } \\
\text { reference number, citation } \\
\text { geography }\end{array}$ & $\begin{array}{l}\text { - } \quad \text { Average reference number is } 23,8 \text {. } \\
\text { - } \quad \text { International studies were more cited. } \\
\text { - } \text { Mersin University ranked first place }\end{array}$ \\
\hline
\end{tabular}


Table 2 summarizes the studies covering specific sections within the entire domestic tourism literature in Turkey. Accordingly, the number of sub-field studies have been gaining momentum for the last decade. Also, quantitative studies dominate other types; both domestic and international studies were seen to be dominantly cited within different sub-fields. Moreover, citations were attributed generally to the disciplines or fields other than tourism, while in-house citations within tourism were limited.

It can be argued that even these studies which are aimed to review a distinct part of the tourism literature are far from the delimiting their scopes therefore, they cannot show the precise gaps within the relevant sub-fields. As a result, there is a need for a literature review study to precisely identify these areas - for which purpose, the present study attempt to answer the questions as follows:

1. Does time as a variable matter for publication abundancy?

2. What is the role of disciplinary diversity in knowledge production?

3. What is the gap within the tourism-economics literature in the context of research topics?

4. Does disciplinary difference matter when addressing the subdivision and main topics of tourism economics?

5. What are the potential gaps within the tourism-economics literature in the context of study design?

6. Does time and disciplinary difference matter for adopting a different kind of study design?

7. Does time and study subject matter when capturing citation(s)?

8. What is the distribution of reference types?

\section{METHOD}

\section{Research Design}

This study covers the published works in Turkey concerning tourism economics between 2000 and 2019. Five categories consisting of four years were determined as a result of splitting the period of 20 years (First Period: 2000, 2001, 2002, 2003. Second Period: 2004, 2005, 2006, 2007. Third Period: 2008, 2009, 2010, 2011. Fourth Period: 2012, 2013, 2014, 2015. Fifth Period: 2016, 2017, 2018, 2019).

As stated previously, lack of any literature review study with the aim to overview the tourism economics literature in Turkey (Yllmaz, 2019:5) has made this study essential. In this context, the research questions were formulated depending on the gaps within the literature. In the following, keyword determination is materialized in accordance with research questions.

All these research questions or parameters are required to be addressed in a way that reflects the status of knowledge in the literature. At this point, capturing a broad range of studies comes to the fore to reflect such a diversely populated research field. Therefore, the keyword spectrum span was enlarged to the extent that concepts covering the tourism-economy nexus could be reached. To do so, textbooks on tourism economics (Bahar \& Kozak, 2012; Ünlüönen et al., 2018) as the fundamental reflections of tourism academics community were consulted to determine the keywords through which the dataset is compiled. In this context. All subdimensions within these books were accepted and searched as keywords, revealing 21 items listed below:

"tourism economics", "tourism financial" , "tourism and demand", "demand chart of tourism", "balance of payment", "demand flexibility", "supply", "supply chart", "supply flexibility", "in-house balance", "indifference curve", "monetary effects of tourism (with sub-titles)", "real effects of tourism (with subtitles)","tourism and inflation", "demand forecast methods in tourism system", "leakage and tourism", "estimation of tourism revenues", "place of tourism in economics", "investment incentives and tourism", "employment in tourism", and "proportion of tourism revenues in GDP".

In the search and selection phase, the "tourism" keyword was added to the concepts that did not have tourismspecific keywords; as a result, the criteria were determined for the inclusion and exclusion of a study in the dataset.

\section{Criteria Determination for Inclusion-Exclusion}

Before searching out and reaching the relevant studies, the criteria were determined for inclusion of studies into the data set whereby the study results accurately reflect the whole body of knowledge. Because most studies published before 2000 could not be accessed online, this date was set as the threshold to ensure a 
proper equilibrium of tourism-economy sub-field. Also, studies published in 2020 were kept out of the scope of the sample as well, and only peer-reviewed journals were considered due to the fact that journals are accepted as the best indicator for tracking the progress within a field or discipline (Cheng et al., 2011). Consequently, conference books, text books, chapters and grey literature were also excluded, along with the printed versions of any documents. In short, only the electronic versions of peer-reviewed journals published within the scope of the Turkish tourism academic community are considered. All journals' published studies in social science were included as well considering that any other journals out of tourism may have published various tourism-related works. After filtration, searching began.

\section{Searching Out Process}

The Google academics and Ulakbim journal databases were used to elicit the electronic version of articles. In this phase, all relevant keywords regarding the intersection of tourism-economic nexus were sought separately. First, the inclusion and exclusion criteria were considered for judging a study to be within the scope of the sample by reading the title, keywords and abstracts of all articles. Following this process, both the reference list and citations referred to pertinent studies were scanned to capture additional studies as recommended by Galvan \& Galvan (2017). This resulted in 331 studies. However, the full texts of 23 studies were unreachable, therefore exempted. Thereafter, the remaining 308 items were re-assessed by considering full texts, resulting in 19 studies to have either irrelevant content with tourism economics or same content with a previously incorporated study. Consequently, 291 studies remained for analysis.

\section{Analysis}

The Tourism studies in extant literature in Turkey has enlarged its span, to the extent that the number of studies published in just 19 journals in Turkey within the period of 2007-2016 was 213 (Güzeller \& Çeliker, 2018). Given, the extent of this study involving the 20 years' period from 2000 to 2019 and all domestic social science journals, it can be predicted that the number of tourism-oriented studies is proportionally large. In this case, systematic or semi-systematic literature review methods are advised (Snyder, 2019, pp. 335-336). Besides, these methods are noteworthy for easing the diagnosis of a slight facet of a field or a discipline (Dupre, 2019, p. 4). Although both methods are useful, the specific research areas within a large of body of literature belonging to a discipline make the semi-structural literature review method essential due to easier overviewing and tracking of a distinctive and complex literature by following a straightforward criteria (Snyder, 2019: p. 335-336).

After choosing the right method, the main criteria were set; first, the full text of each article was read thoroughly in accordance to the parameters. After ensuring that the context overlaps with the criteria, coding was initiated on the 291 studies based on the list developed during the process within an SPSS File, except the main subject categories since this phase contains capturing the main themes and, then, assembling synonymous themes under the same categories to code them into a higher level. All the other variables were coded as determined previously. During the analysis, first the abstracts of filtered studies were re-read to determine the nature of the work; in the event that one or more of the aforementioned parameters were omitted, relevant information was sought from related sub-section titles within the study (Wu et al., 2012). Then, the reference lists of all studies were counted one by one for each studies. This period involved grouping all references according to the type of publication (research article, conference paper, book, report, internet source and other sources) and coding the frequency of all types of publications. Lastly, each study was googled on the Google Scholar to determine the number of citations. This value was entered as a distinct variable. After completing all of these processes, the analysis was initiated for frequency, cross tabulations and regression.

The Literature review phase structured in the methodology section of this study was conducted by adopting the course of implementation of (McColl-Kennedy et al., 2017; Tranfield et al., 2003) as well as taking into account the recommendations of (Dupre, 2019; Snyder, 2019).

\section{FINDINGS}

In the finding section, an overview on tourism economic sub-literature was made, as in Table 3, where almost all criteria were explicated and examined based on specific factors.

\section{Overview on the Tourism Economics Sub-literature}

The information in Table 3 regarding the characteristics of Turkish tourism-economics literature stands as the sum of the whole knowledge within the sub-literature. 
Table 3: Overview of the tourism economics sub-literature in Turkey

\begin{tabular}{|c|c|c|c|}
\hline Criteria & $(\mathrm{n})$ & \multicolumn{2}{|c|}{$(\%)$} \\
\hline Publication Period & (n) & \multicolumn{2}{|c|}{$(\%)$} \\
\hline $2000-2003$ & 7 & \multicolumn{2}{|c|}{2,4} \\
\hline $2004-2007$ & 30 & \multicolumn{2}{|c|}{10,3} \\
\hline 2008-2011 & 40 & \multicolumn{2}{|c|}{13,7} \\
\hline $2012-2015$ & 85 & \multicolumn{2}{|c|}{29,2} \\
\hline 2016-2019 & 129 & \multicolumn{2}{|c|}{44,3} \\
\hline Total & 291 & \multicolumn{2}{|c|}{100} \\
\hline Subject Area of economics & (n) & \multicolumn{2}{|c|}{$(\%)$} \\
\hline Macroeconomics & 179 & \multicolumn{2}{|c|}{61,5} \\
\hline Microeconomics & 112 & \multicolumn{2}{|c|}{38,5} \\
\hline Total & 291 & \multicolumn{2}{|c|}{100} \\
\hline Disciplinary Equilibrium of Authors & (n) & \multicolumn{2}{|c|}{$(\%)$} \\
\hline Economics and Administrative Sciences (EAS) & 165 & \multicolumn{2}{|c|}{56,7} \\
\hline Tourism & 72 & \multicolumn{2}{|c|}{24,7} \\
\hline EAS and Tourism (Collaboration) & 35 & \multicolumn{2}{|c|}{12,0} \\
\hline The Other & 19 & \multicolumn{2}{|c|}{6,5} \\
\hline Total & 291 & \multicolumn{2}{|c|}{100} \\
\hline \multicolumn{4}{|l|}{ Study Design } \\
\hline Quantitative & 202 & \multicolumn{2}{|c|}{69,4} \\
\hline Qualitative & 63 & \multicolumn{2}{|c|}{21,6} \\
\hline Conceptual & 26 & \multicolumn{2}{|c|}{8,9} \\
\hline Total & 291 & \multicolumn{2}{|c|}{100} \\
\hline \multicolumn{4}{|l|}{ Citation Count Ranges } \\
\hline Between $0-1$ citation range & 64 & \multicolumn{2}{|c|}{22,0} \\
\hline Between 2-5 citation range & 80 & & \\
\hline Between 6-10 citation range & 45 & & \\
\hline Between 11-19 citation range & 43 & & \\
\hline Over 20 citations & 58 & & \\
\hline Total & 291 & & \\
\hline References Types & $\bar{x}$ & Min & Max \\
\hline Reference List Mean Counts of the All Literature & 33,03 & 9 & 94 \\
\hline Reference Geography & & & \\
\hline Domestic Publications & 15,26 & 0 & 71 \\
\hline International Publications & 17,49 & 0 & 79 \\
\hline Reference Type & & & \\
\hline Journal & 21,31 & 0 & 72 \\
\hline Book & 5,35 & 0 & 21 \\
\hline Report & 3,21 & 0 & 22 \\
\hline Other sources & 1,50 & 0 & 5 \\
\hline Web Sites & 1,45 & 0 & 23 \\
\hline Conference Paper & 0,85 & 0 & 11 \\
\hline Dissertation & 0,77 & 0 & 16 \\
\hline Citation Captured & 15,73 & 0 & 217 \\
\hline
\end{tabular}

Accordingly, a geometric rise appears in the tourism economic studies across the time period. Also, studies in macroeconomics are seen to get ahead of microeconomics. The studies were dominantly carried out by authors at the department of EAS, whereas the tourism academic community seems to lack interest in studying this mature sub-field. Similarly, quantitatively designed studies are three times more than qualitatively and conceptually designed ones. The citation number captured as well as the geography of references remain fairly 


\section{Y. K. Özekici 13/1 (2021) 790-812}

consistent across all ranges, except those representing 2-5 citations on average. Journal articles come into prominence as the most widely benefited source, in contrast to dissertations as the least utilized.

\section{Study Subjects, Main Topics and Subtopics}

In this subsection, the study subjects, main topics and subtopics within the tourism economics sub-field are extracted based on different variables.

Table 4: Study Subjects, Main Topics and Subtopics within Tourism Economics Sub-Field

\begin{tabular}{|c|c|c|c|c|}
\hline $\begin{array}{l}\text { Subdivision of } \\
\text { Economics } \\
(\mathrm{n}) /(\%)\end{array}$ & $\begin{array}{l}\text { Main Topic } \\
(\mathrm{n}) /(\%)\end{array}$ & Subtopics & (n) & $(\%)$ \\
\hline \multirow{25}{*}{$\begin{array}{l}\text { Microeconomics } \\
(112) /(38,5)\end{array}$} & \multirow{6}{*}{$\begin{array}{c}\text { Financial } \\
\text { performance } \\
\text { of tourism } \\
\text { companies } \\
(41) /(36,6)\end{array}$} & $\begin{array}{l}\text { Financial performance evaluation of tourism } \\
\text { companies }\end{array}$ & 26 & 63,4 \\
\hline & & $\begin{array}{l}\text { Factors effecting financial performance of } \\
\text { tourism companies }\end{array}$ & 6 & 14,7 \\
\hline & & $\begin{array}{l}\text { Financial problem analysis of tourism } \\
\text { enterprises }\end{array}$ & 4 & 9,7 \\
\hline & & Financial rate analysis of tourism enterprises & 3 & 7,4 \\
\hline & & $\begin{array}{l}\text { Role of financial performance of tourism } \\
\text { companies on profitability }\end{array}$ & 1 & 2,4 \\
\hline & & $\begin{array}{l}\text { Antecedents of profit/net return of tourism } \\
\text { companies in stock market }\end{array}$ & 1 & 2,4 \\
\hline & \multicolumn{2}{|r|}{ Total } & 41 & 100 \\
\hline & \multirow{11}{*}{$\begin{array}{l}\text { Tourism } \\
\text { Demand } \\
(37) /(33,0)\end{array}$} & Forecasting tourism demand & 23 & 62,1 \\
\hline & & Role of numerous factors on tourism demand & 3 & 8,1 \\
\hline & & Relation between tourism demand and revenue & 2 & 5,4 \\
\hline & & $\begin{array}{l}\text { Relation between tourist expenditure and } \\
\text { tourism revenue }\end{array}$ & 2 & 5,4 \\
\hline & & Effect of demand shocks on Tourism sector & 1 & 2,7 \\
\hline & & $\begin{array}{l}\text { Relation between tourism demand and } \\
\text { exchange rate shocks }\end{array}$ & 1 & 2,7 \\
\hline & & Role of monetary policy on tourism demand & 1 & 2,7 \\
\hline & & $\begin{array}{l}\text { Effect of international touristic promotion on } \\
\text { tourism demand }\end{array}$ & 1 & 2,7 \\
\hline & & $\begin{array}{l}\text { Relation between tourism demand and } \\
\text { economic growth }\end{array}$ & 1 & 2,7 \\
\hline & & $\begin{array}{l}\text { Relation between tourism demand and tax } \\
\text { revenues }\end{array}$ & 1 & 2,7 \\
\hline & & $\begin{array}{l}\text { Relation between international trade and } \\
\text { tourism demand }\end{array}$ & 1 & 2,7 \\
\hline & \multicolumn{2}{|r|}{ Total } & 37 & 100 \\
\hline & \multirow{4}{*}{$\begin{array}{l}\text { Tourism } \\
\text { Supply } \\
(5) /(4,5)\end{array}$} & $\begin{array}{l}\text { Determination of tourism supply capacity of } \\
\text { accommodation enterprises }\end{array}$ & 2 & 40 \\
\hline & & Determining factors on tourism supply & 1 & 20 \\
\hline & & $\begin{array}{l}\text { Role of specific tourist segment on tourism } \\
\text { sector }\end{array}$ & 1 & 20 \\
\hline & & Tourism product value creation & 1 & 20 \\
\hline & \multicolumn{2}{|r|}{ Total } & 5 & 100 \\
\hline & & Role of policy crisis on tourism sector & 6 & 20,6 \\
\hline
\end{tabular}


Y. K. Özekici 13/1 (2021) 790-812

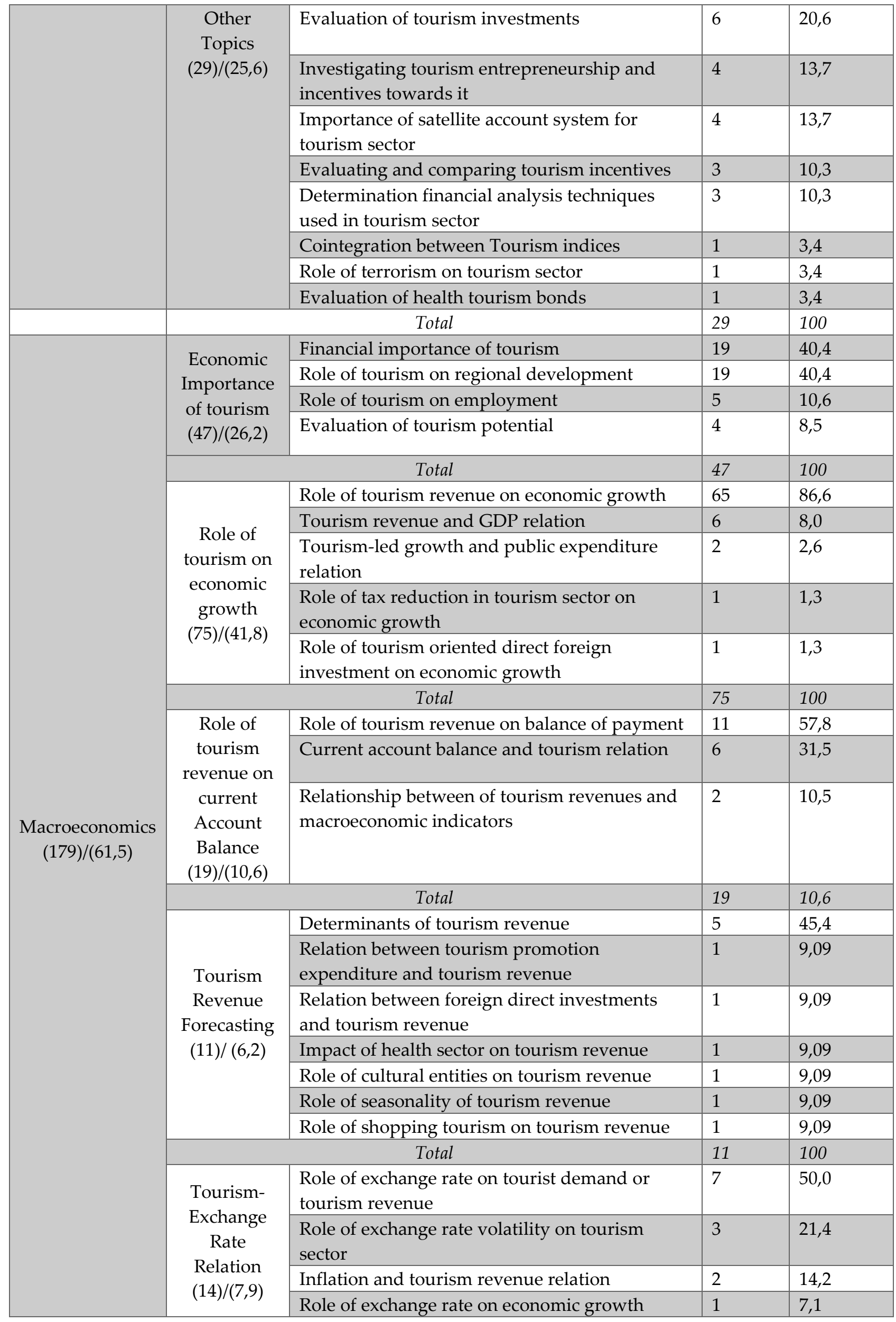


Y. K. Özekici 13/1 (2021) 790-812

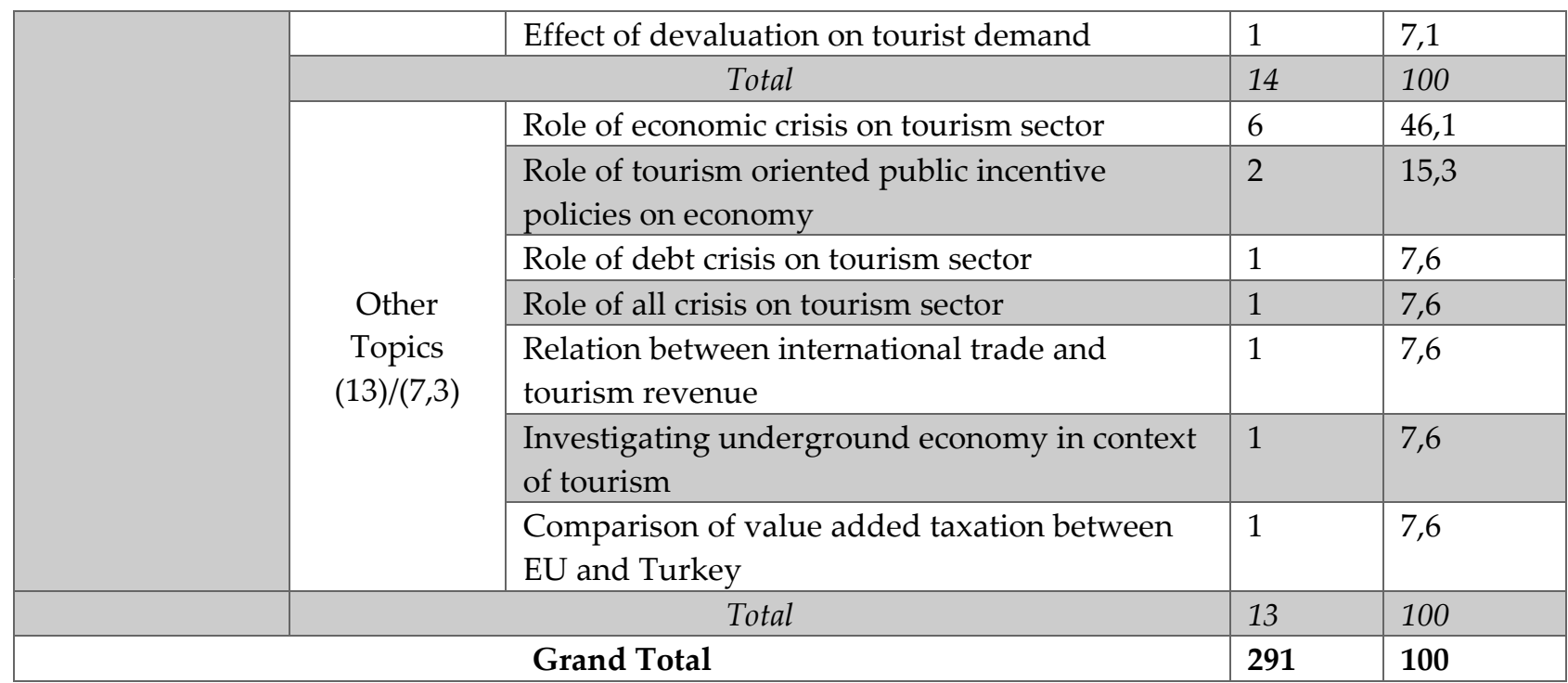

In table 4, there are two subdivisons, 10 main topics and 62 subtopics representing a snapshot of the tourism economics literature in the context of Turkish economic community.

For studies on the microeconomic subdivision, it is surprising to see that the financial importance of tourism companies is the most studied main topic compared to the main study areas of tourism economics, such as tourism demand and tourism supply. Also, tourism supply lacks the interest of academic community in Turkey because it is rather underrepresented. Also, the other important aspects of tourism economics are addressed only narrowly, thus their grouping under the other topics both in microeconomics and macroeconomics subdivisions. Another aspect of macroeconomics is based on five frequently addressed main topics. Intrinsically, the main divergence stemming from the variations between two subdivisions based on frequency is seen to be caused by the element within the main topics as the "role of tourism in economic growth", more specifically, studies dealing with the relation between tourism revenue and economic/GDP growth distinguished the macroeconomic studies. The other topics under this category are, indeed, formed based on numerous crises in the tourism sector.

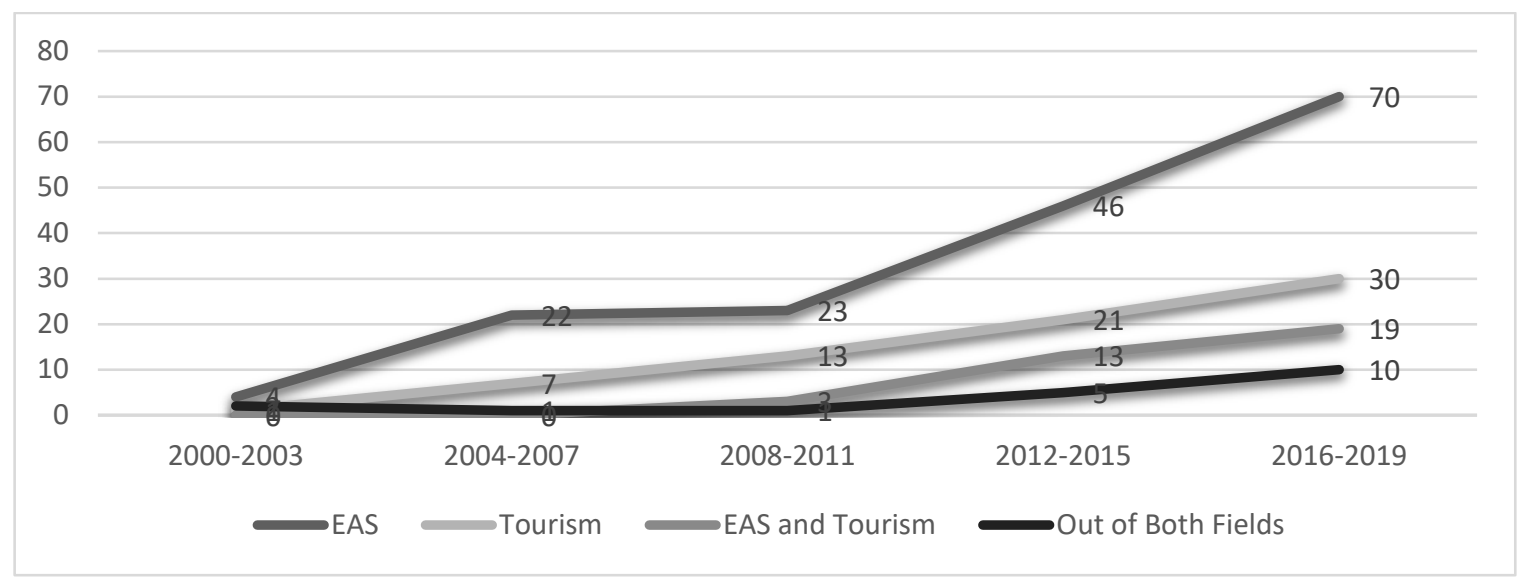

Figure 1: Disciplinary distribution on tourism-economic studies (n)

Figure 1 reveals the period between 2008 and 2011 is a peak point triggering the proliferation of publications across almost all fields related to tourism economics. Yet, the authors from the department of EAS appear to have more studies than others. 


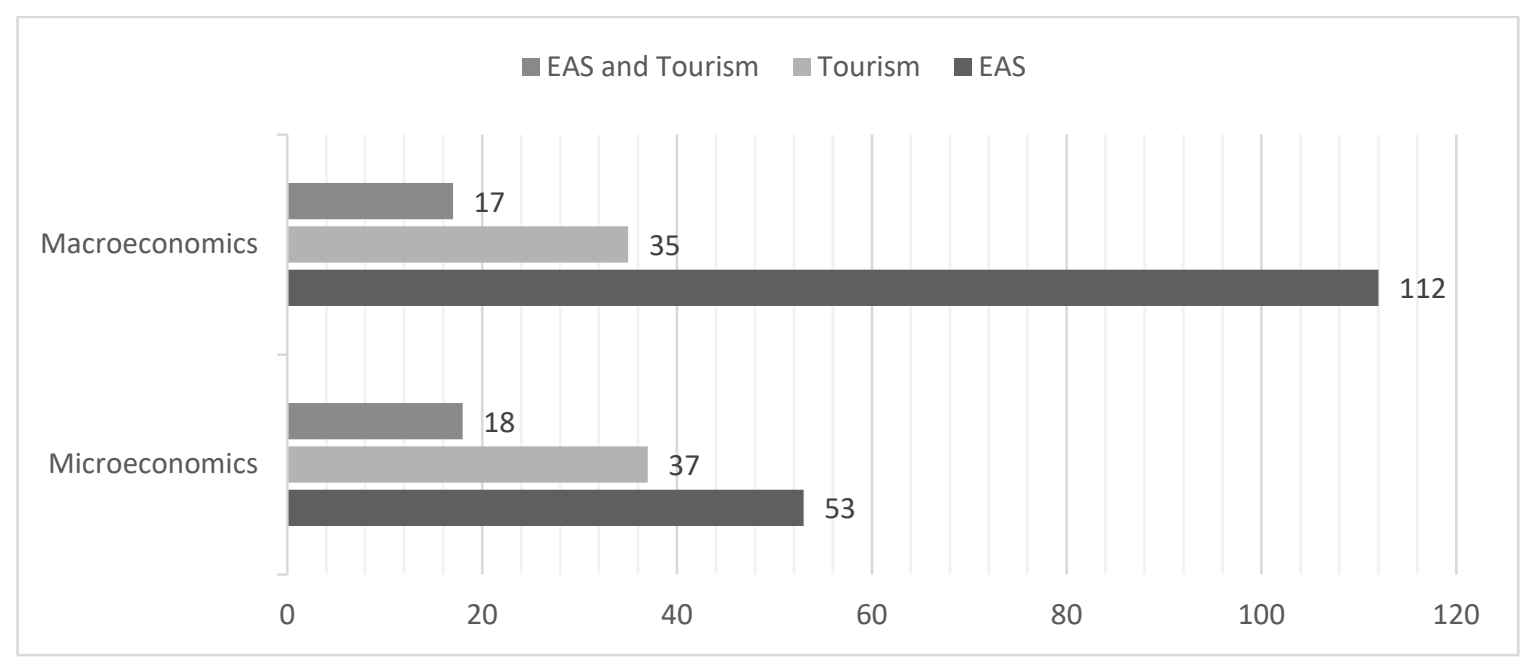

Figure 2: Disciplinary distribution on subdivision of economics (n)

From Figure 2, it can be inferred that the role of EAS department in academic output within the tourismacademic sub-literature is more significant than the tourism department in terms of both macro- and microeconomics, generating more studies. To ensure accuracy, more detailed scrutiny was carried out in terms of the main topics, as follows.

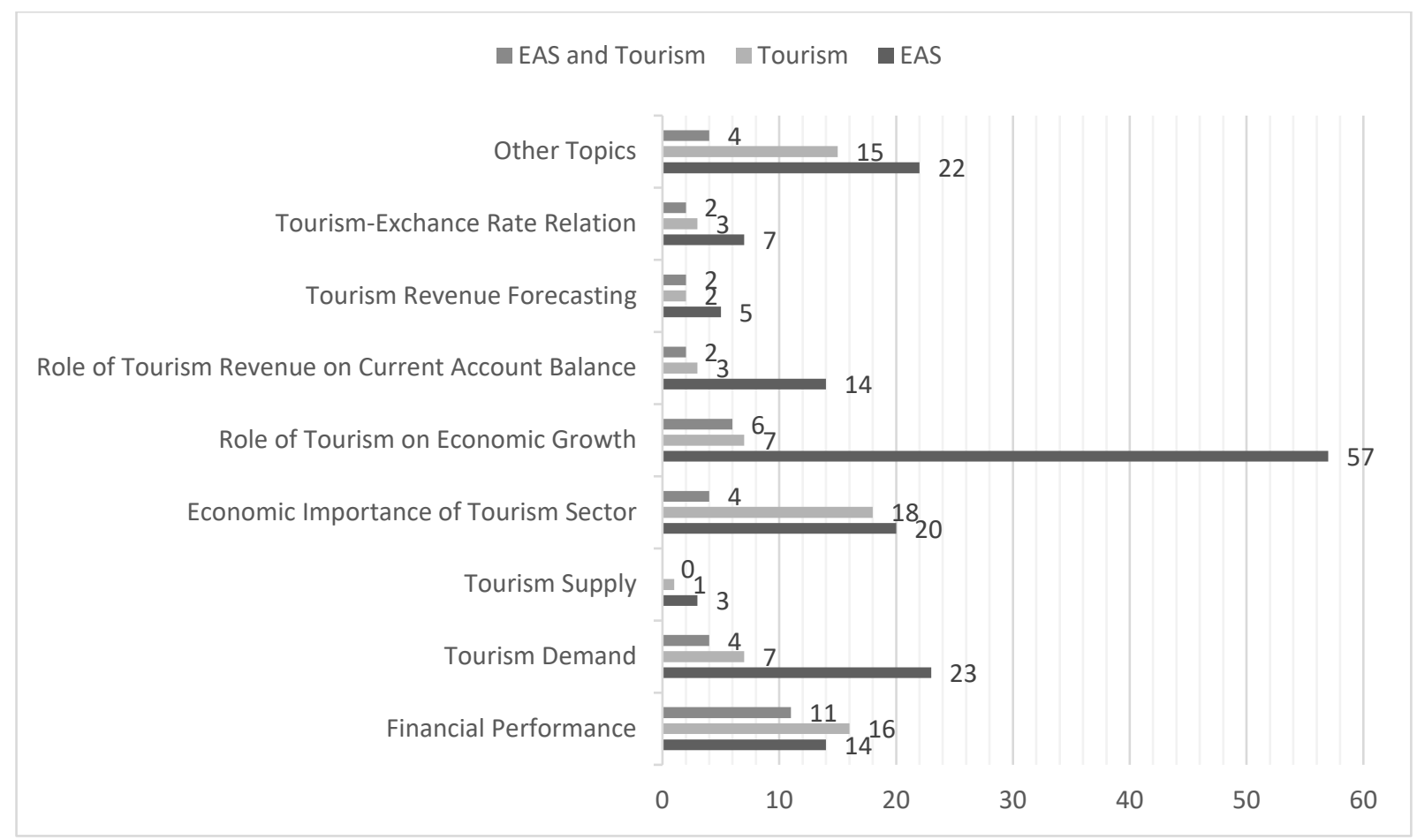

Figure 3: Disciplinary distribution on main topics of economics (n)

Figure 3 clearly illustrates that the academic output of EAS exceeds that of tourism in the scope of almost all main topics, except for the financial performance evaluation of tourism companies.

\section{Study Designs}


Table 5: Study Designs and Sub designs within Tourism Economics Sub-Field

\begin{tabular}{|c|c|c|c|}
\hline $\begin{array}{l}\text { Study Design } \\
\text { (n)/(\%) }\end{array}$ & Sub design & (n) & $(\%)$ \\
\hline \multirow{17}{*}{$\begin{array}{l}\text { Quantitative } \\
(201) /(69,0)\end{array}$} & $\begin{array}{l}\text { Causality analysis (Hatemi } \\
\text { J/Granger/Yamamto/Granger/Johansen } \\
\text { etc.) }\end{array}$ & 30 & 14,9 \\
\hline & Panel data & 23 & 11,4 \\
\hline & Multiple approaches & 21 & 10,9 \\
\hline & ARDL & 13 & 6,5 \\
\hline & VAR analysis & 12 & 5,9 \\
\hline & Cointegration test & 10 & 5,0 \\
\hline & Regression/Correlational analysis & 10 & 5,0 \\
\hline & Unit root test & 10 & 5,0 \\
\hline & Input/output analysis & 6 & 3,0 \\
\hline & Ratio analysis & 6 & 3,0 \\
\hline & Time series analysis & 6 & 3,0 \\
\hline & Ordinary least squares (OLS) & 5 & 2,5 \\
\hline & Questionnaire & 4 & 1,9 \\
\hline & Neural network analysis & 3 & 1,4 \\
\hline & Data envelopment & 3 & 1,4 \\
\hline & Content analysis & 2 & 0,9 \\
\hline & The Others* & 37 & 18,3 \\
\hline \multicolumn{2}{|r|}{ Total } & 201 & 100 \\
\hline \multirow{3}{*}{$\begin{array}{l}\text { Qualitative } \\
(64) /(21,9)\end{array}$} & Table & 53 & 84,1 \\
\hline & TOPSIS & 6 & 9,5 \\
\hline & SWOT & 5 & 7,9 \\
\hline \multicolumn{2}{|r|}{ Total } & 64 & 100 \\
\hline Conceptual $(26) /(8,9)$ & Conceptual & 26 & 100 \\
\hline \multicolumn{2}{|r|}{ Grand Total } & 291 & 100 \\
\hline
\end{tabular}

* The other studies are papers drawing on separate methods from each other.

** The tables were applied as with the qualitative methods adopted by (Mohammed et al., 2015)

In Table 5 related to the methodological designs, it is seen that quantitative studies have an important place within the literature. Within it, causality analysis, panel data and multiple approaches were determined as the most significant factors. Apart from this, questionnaires as a leading data acquisition tool for empirical studies conducted by management, marketing and tourism fields are seen not to draw sufficient interest within the tourism-economic literature. Besides, qualitative- and conceptual-based papers appear to lack methodological diversity. These works mostly comprise tables, which depend on secondary data instead of developing novel knowledge.

Although this data gives an impression of the circumstances concerning tourism-economics, a further indepth view is developed in Figures 4 and 5. 


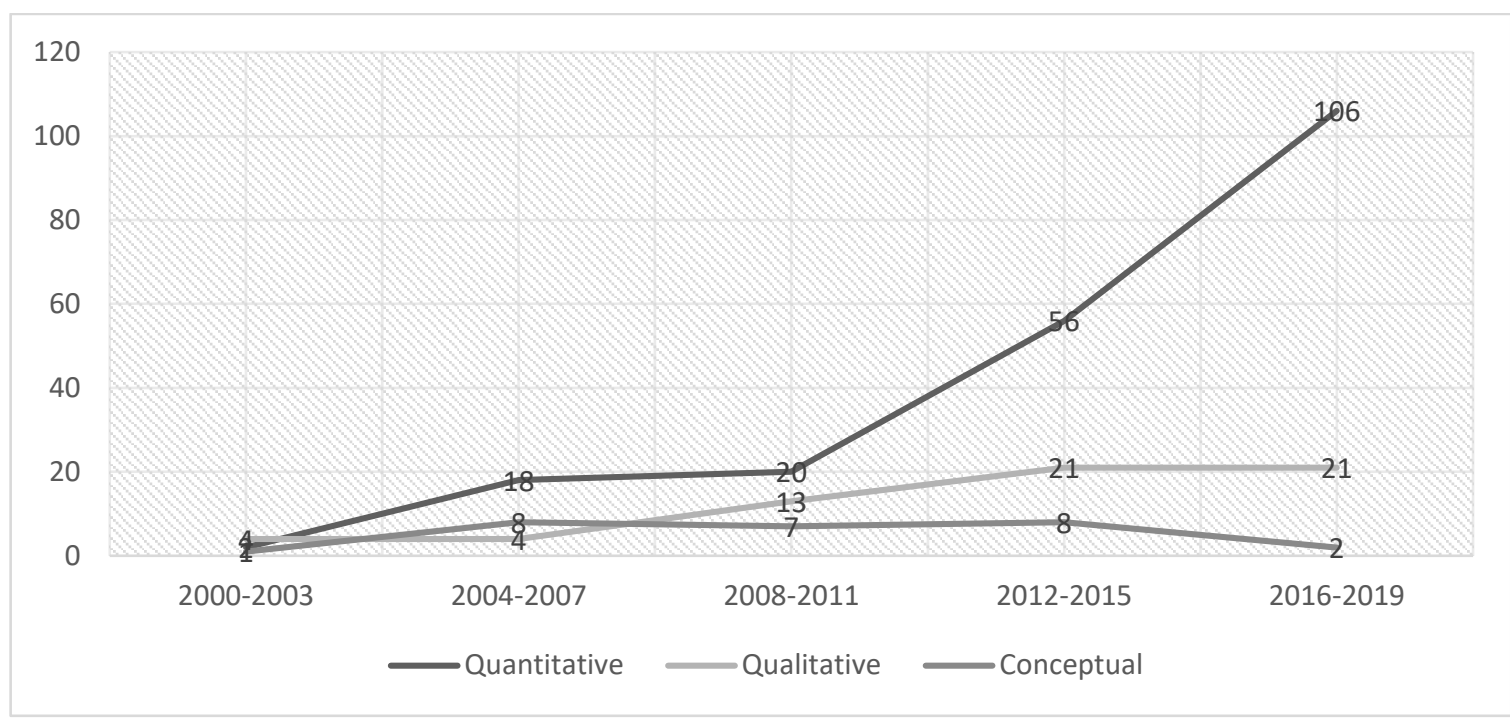

Figure 4: Pattern of study design within five study periods $(n)^{*}$

*Other categories outside of management, tourism and management-tourism categories were ignored due to the low representability.

In Figure 4, it can be seen that 2008-2011 is a turning point for the quantitatively designed studies as they begin to gain momentum as of 2008 onwards. Conversely, conceptual studies fell from favour as time passed, until the present.

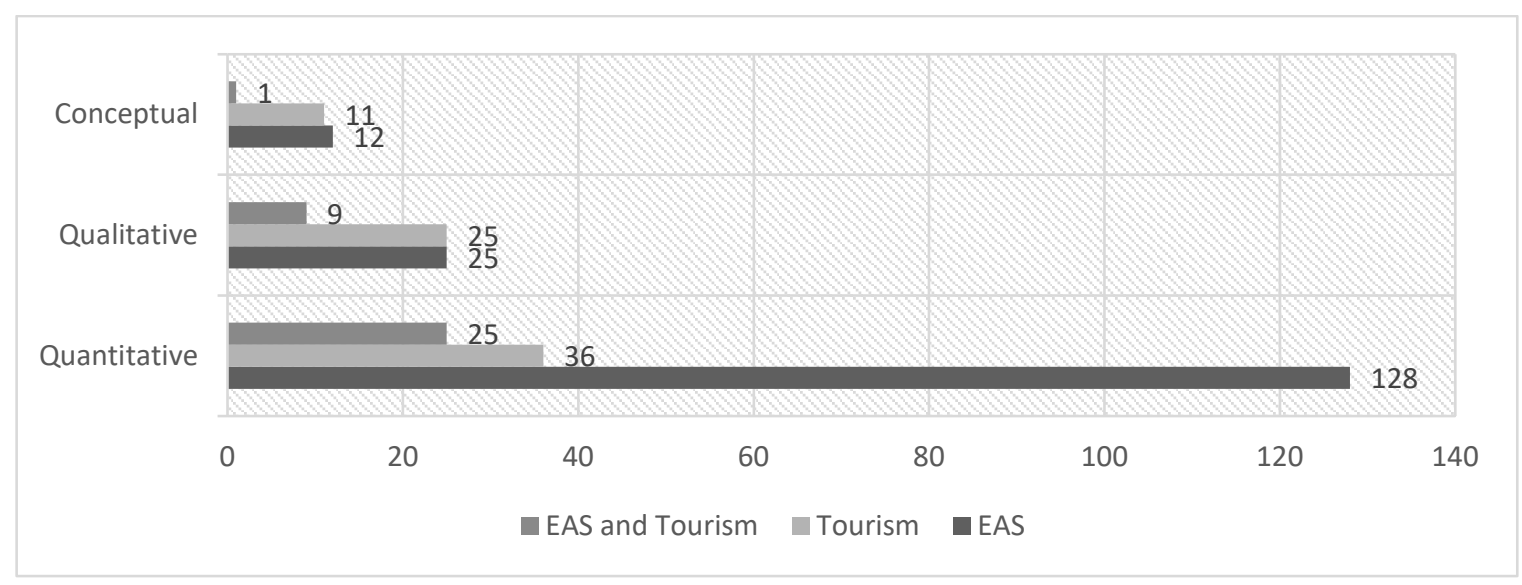

Figure 5: Disciplinary distribution on study designs (n)

${ }^{*}$ Other categories outside of management, tourism and management-tourism categories were ignored due to the low representability.

Figure 5 delineates the dominancy of EAS department in quantitative based-knowledge production, and the articles on this subject seem to be predominantly prepared by authors from the discipline itself. The other methods were adopted equally by both tourism and EAS.

\section{Citations}

Due to lack of a theory explicating all factors which are determinative for a study to be cited (Xiao \& Smith, 2008), the present work adopts and determines the main parameters as a factor to explain whether they are key to capturing citations. The parameters are the study period and the subject. Also, the disciplinary variation factor was considered to see if inbreeding has an empirical ground. 


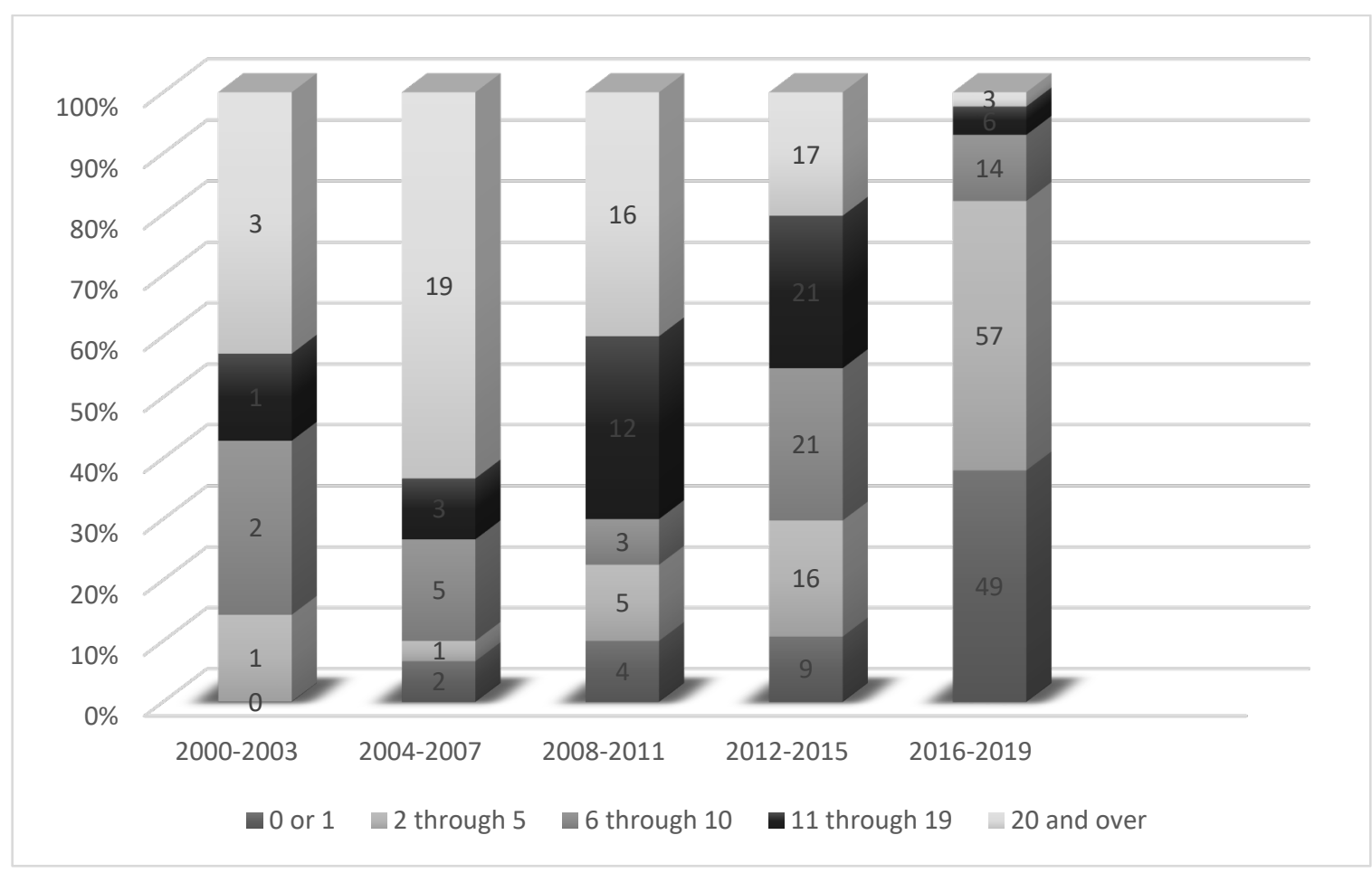

Figure 6: Publication period and citation frequency (n)

When Figure 6 is examined, it is evident that with time, studies distinctively capture more citations. To provide more evidence, a linear regression analysis was performed between two variables and a significant relation was determined $(-0,570, \mathrm{p}<0,01)$, hence proving the validity of the above statement and the fact that the publication period variable can account for over fifty percent of how a study captures citations. The other potential variables have been listed in Table 6 .

Table 6: Citation frequency means of studies according to specific criteria

\begin{tabular}{|c|c|c|c|}
\hline Criteria & $\bar{x}$ & Min & $\operatorname{Max}$ \\
\hline \multicolumn{4}{|l|}{ Subdivision of Economics } \\
\hline Macroeconomics & 19,20 & 0 & 217 \\
\hline Microeconomics & 10,22 & 0 & 60 \\
\hline \multicolumn{4}{|l|}{ Main Topics } \\
\hline Role of tourism in economic growth & 23,95 & 0 & 194 \\
\hline Economic Importance of tourism & 23,49 & 0 & 217 \\
\hline Tourism Revenue Forecasting & 14,09 & 0 & 78 \\
\hline Role of tourism revenue in Current Account Balance & 10,79 & 0 & 63 \\
\hline Financial performance of tourism companies & 10,61 & 0 & 60 \\
\hline Tourism Demand & 9,89 & 0 & 59 \\
\hline Tourism-Exchange Rate Relation & 6,21 & 0 & 19 \\
\hline Tourism Supply & 3,20 & 0 & 7 \\
\hline \multicolumn{4}{|l|}{ Study Design } \\
\hline Conceptual & 22,54 & 0 & 120 \\
\hline Qualitative & 16,60 & 0 & 217 \\
\hline Quantitative & 14,58 & 0 & 194 \\
\hline \multicolumn{4}{|l|}{ Discipline } \\
\hline Management & 19,31 & 0 & 217 \\
\hline Management and Tourism & 12,41 & 0 & 68 \\
\hline Tourism & 10,42 & 0 & 120 \\
\hline Citation Mean of All Studies & 15,73 & 0 & 217 \\
\hline
\end{tabular}


As Table 6 is observed, it becomes obvious that studies designed within macroeconomics were cited more compared to those in microconomics. Also, more definite information can be reached under the main topics in those studies regarding the role of tourism on economic growth, and economic importance appears to be a decisive factor in capturing citations. On the other hand, studies concerning tourism supply seem to be out of the scope of interest among academic community. Also, the mean value of citations in the context of study design is surprising, perhaps due to the low interest in quantitative studies. The role of discipline implies that the presence of the EAS discipline induces a citation-oriented impact within the tourism-economics subliterature.

\section{CONCLUSION AND DISCUSSION}

The aim of this study is to shed light on the status of studies related to domestic tourism economics within the Turkish academic community in the context of subject area, study design and citation frequency. Also, the publication date and disciplinary equilibrium of the authors are evaluated as determinant factors within the above contexts. Accordingly, it was seen that the last publication period involving the most publications is in accordance with the extant literature (Arıca, 2014; Bayın, 2015; Bozok et al., 2017; Özel \& Kozak, 2012; Tayfun et al., 2016). However, in contrast to Mohammed et al. (2015), macroeconomic-oriented topics were found to be more under study than microeconomics, a discrepancy that may stem from the high dependency of Turkish economy on tourism revenue which in turn may be proliferating the studies on the relation between the two. Similarly, authors outside of tourism field were seen to produce more studies which dissociated with (Temizkan et al., 2015). The preferred reference geography reveals a surprising result as well since, in contrast to the finding of Özel \& Kozak (2012), Kervankıran et al. (2019) as well as (Düşmezkalender \& Metin, 2019; Şahin \& Acun, 2015), the reference list of the extant literature shows a balanced distribution regarding the geography of references similar to that determined by (Baytok et al., 2019). This difference may be associated with the comparatively high number of authors from the EAS department. Also, being a mature discipline, economy studies are abundant within the domestic literature, in turn likely to facilitate relevant studies within the same scope. Additionally, this situation might stem from other bibliometric studies; for the reference type, journals were determined to be the first preferred source. This finding is similar to that found for tourism marketing studies (Özel \& Kozak, 2012); however, the average number of studies in the reference lists is found to be more than those from other fields such as gastronomy (Sökmen \& Özkanlı, 2018). The difference between these studies may be due to the maturity of source disciplines.

The role of tourism in economic growth and in current account balance come into prominence as the largest study subjects among all subdivisions and main topics and coincide with the international literature (Comerio \& Strozzi, 2019; Wu et al., 2012). Yet, as for the main topics, the mostly observed issues within the international literature, such as demand and supply (Mohammed et al., 2015; Wu et al., 2012), do not appear to draw sufficient interest from the Turkish literature. This finding may imply that the attributed role of the tourism sector in the Turkish economy is directly reflected in the output of Turkish academic community; the leading frequency of macroeconomic studies can be interpreted in the same way. On the other hand, it was seen that the unstable exchange rates for almost all currencies against the Turkish lira have not been addressed adequately. Therefore, this study area may serve as a gap to be filled by future studies. Also, tourism supply is seen to lack interest by the academic community in Turkey. This situation may result from the oversupplying of tourism products beginning in the 1980s, thus perceived invaluable as a topic. Conversely, other gaps such as novel study areas that remained out of the spotlight include acculturation (Özekici \& Ünlüönen, 2019), tips in restaurants (Yılmaz, 2017a), halal tourism (Olcay et al., 2018) or role of large-scaled investments for regional development (Arslan, 2020) in vast ex for future bibliometric studies.

The disciplinary distribution of authors over time showed that those from both tourism and EAS have collaborated more than in the past. This finding may imply that interdisciplinary studies have been gaining momentum within the tourism economics sub-literature. On the other hand, increasing interest from disciplines outside of both tourism and EAS fields over two decades can be accepted as a cue for the enhancing specialization in the tourism-economics literature. The reason for this inference is the extraordinary rise of quantitatively designed studies requiring expertise up to a certain level. For disciplinary distribution in subdivision and main topics, it was explicitly delineated that the EAS field has more importance than tourism 
field; the only exception for this situation is the financial performance of tourism companies. The reason for this divergence is that a tourism scholar (e.g. Karadeniz \& Öcek, 2019) focused on the financial performance of tourism companies and produced several studies on the subject.

Supporting the general status of the international tourism knowledge platform (Wu et al., 2012), the domestic studies in the tourism-economics subfield were generally seen to be designed based on quantitative methods. This finding is in line with previous findings in the context of various tourism sub-fields (Arıca, 2014; Aydın, 2017; Evren \& Kozak, 2014; Işık et al., 2019; Temizkan et al., 2015; Yeşilyurt \& Koçak, 2018; Yılmaz, 2017b), while contrasting with Sökmen \& Özkanlı (2018). The dominancy of quantitative methods is in agreement with Popper's opinion on the positivistic aspect of tourism economics studies (Liburd, 2012). Also, the underrepresentation of qualitative method in the Turkish academic community could mean that the interpretive approach has not been adequately adopted in this community. Nonetheless, the domestic tourism academic community appears determined to prefer both methods in a balanced manner, as revealed by (Darbellay \& Stock, 2012). The strong representation of both quantitative and qualitative methods inside the tourism academic community underpins Bruner (2010)'s discourse that there are numerous paradigm adoptions within the field of tourism. Yet, other findings do not point to the same fact. As the fields were compared according to the sub-design of studies across various disciplines, it could be seen that some mostly prefer to draw on questionnaires and other methods based on correlation and regression techniques; these however, constitute only a small proportion of all research, as indicated by (Baytok et al., 2019). Especially, Arıkan-Saltık (2020), and Şahin \& Acun (2015)'s findings on questionnaire forms found them to be the most widely used instrument, hence supporting the argument. Also, when taking the research method into consideration as a sub-design of relevant literature, the conceptual design was seen to prevail against qualitative designed at the outset of researches. Reid \& Andereck (1989) refer to the dominating role of conceptual papers. Yet, qualitative methods were also seen to take the dominating role of conceptual papers, contradicting (Temizkan et al., 2015) as for the 2008-2011 period. Many of the qualitatively oriented studies have been designed in a limited manner in the context of which secondary data to be compiled within tables.

Although input-output analysis (Wu et al., 2012), as well as regression analysis (Mohammed et al., 2015), emerged as the mostly utilized sub-designs within the international tourism knowledge platform, they do not hold the same popularity among the Turkish scholars. The reason for this is choosing mostly the causality models believed to perform well (Song et al., 2012). This notion within the tourism economics studies can be a cue that the Turkish academic community is perhaps well-organized in terms of methodological aspects; however, this is only valid for the authors from EAS because the tourism academic community clearly lacks interest in the quantitative econometric models, apart from some exceptions.

\section{REFERENCES}

Arıca, R. (2014). Seyahat işletmeciliği literatürünün gelişim süreci: Türkiye'de hazırlanan lisansüstü tez çalışmalarının bibliyometrik olarak incelenmesi. VII. Lisansüstü Turizm Öğrencileri Araştırma Kongresi. Kuşadası, Türkiye.

Arıkan-Saltık, I. (2020). Turist rehberliği konulu ulusal lisansüstü tezlerin bibliyometrik profili (1989-2018). Çankırı Karatekin Üniversitesi Sosyal Bilimler Enstitüsü Dergisi, 11(1), 45-69.

Arslan, E. (2020). Yeni Tokat havalimanı'nın bölgesel turizm hareketlerindeki rolü: Memleket ziyaretleri kapsamında bir araştırma. Tourism and Recreation, 2(2), 97-105.

Aydın, B. (2017). Yükseköğretim kurulu tez merkezinde (yöktez) yiyecek içecek işletmeciliği alanında kayıtlı bulunan tezlerin bibliyometrik analizi. Disiplinlerarası Akademik Turizm Dergisi, 2(1), 23-38.

Bahar, O., \& Kozak, M. (2012). Turizm Ekonomisi (4. Baskl). Detay Yayıncılık.

Bayın, G. (2015). Türkiye'de Sağlık Turizmi Alanında Yapılan Lisansüstü Tezlerin İçerik Değerlendirmesi. Karamanoğlu Mehmetbey Üniversitesi Sosyal Ve Ekonomik Araştırmalar Dergisi, 2015(1), 55.

Baytok, A., Boyraz, M., Çetin, A., Mutlu, H., \& Katırcıŏlu, E. (2019). Etik ve sosyal sorumluluk konulu bildirilerin bibliyometrisi: Ulusal Turizm Kongreleri örneği (2009-2017). Güncel Turizm Araştırmaları Dergisi, 3(1), 65-81. 


\section{Y. K. Özekici 13/1 (2021) 790-812}

Boğan, E., Çalışkan, C., \& Dedeoğlu, B. (2018). Turizm Yazınında Kurumsal Sosyal Sorumluluk: Türkiye'de Yapılan Çalışmaların Bibliyometrik Analizi. Turizm Akademik Dergisi, 5(2), 47-62.

Botterill, D., Haven, C., \& Gale, T. (2002). A survey of doctoral theses accepted by universities in the UK and Ireland for studies related to tourism, 1990-1999. Tourist Studies, 2(3), 283-311.

Bozgeyik, Y., \& Kutlu, A. (2019). Türkiye'de Cari Açığın Belirleyicileri: 1992-2017 Dönemi İçin Ampirik Çalışma. Maliye Dergisi, 176, 1-26.

Bozgeyik, Yusuf, \& Yoloğlu, Y. (2015). Türkiye'de Turizm Gelirleri İle Gsyh Arasindaki İlişki: 2002-2014 Dönemi. Uluslararası Sosyal Araştırmalar Dergisi, 8(40), 627-640.

Bozok, D., Kılıç, S. N., \& Özdemir, S. S. (2017). Bibliometric analysis of rural tourism on tourism literature Turizm literatüründe kırsal turizmin bibliyometrik analizi. Journal of Human Sciences, 14(1), 187-202.

Bruner, E. M. (2010). Science and Humanism in Tourism Studies. In Annals of Tourism Research, 37(3), 861-865.

Butler, R. (2015). The evolution of tourism and tourism research. Tourism Recreation Research, 40(1), 16-27.

Canosa, A., Moyle, B. D., Moyle, C., \& Weiler, B. (2018). Anthropology and sociology in tourism doctoral research. Tourist Studies, 18(4), 375-398.

Çapar, G., Toksöz, D., \& Dönmez, B. (2018). Turist Rehberliği Alanında Yapılan Akademik Çalışmaların İncelenmesi. Turist Rehberliği Dergisi, 1(2), 57-73.

Carr, N., \& Hayes, S. (2017). An analysis of trends in Ph.D. research in tourism. Tourism Recreation Research, $42(1), 32-44$.

Cheng, C. K., Li, X. R., Petrick, J. F., \& O'Leary, J. T. (2011). An examination of tourism journal development. Tourism Management, 32(1), 53-61.

Comerio, N., \& Strozzi, F. (2019). Tourism and its economic impact: A literature review using bibliometric tools. Tourism Economics, 25(1), 109-131.

Darbellay, F., \& Stock, M. (2012). Tourism as complex interdisciplinary research object. Annals of Tourism Research, 39(1), 441-458.

Dupre, K. (2019). Trends and gaps in place-making in the context of urban development and tourism: 25 years of literature review. Journal of Place Management and Development, 12(1), 102-120.

Düşmezkalender, E., \& Metin, M. (2019). Alternatif Turizme Yönelik Bibliyometrik Bir Araştırma. Selçuk Üniversitesi Sosyal Bilimler Meslek Yüksekokulu Dergisi, 22(2), 813-824.

Evren, S., \& Kozak, N. (2014). Bibliometric analysis of tourism and hospitality related articles published in Turkey. Anatolia, 25(1), 61-80.

Franklin, A., \& Crang, M. (2001). The trouble with tourism and travel theory? Tourist Studies, 1(1), 5-22.

Galvan, J. L., \& Galvan, M. C. (2017). Writing Literature Reviews (7nd Edition). Routledge.

Gülcan, B. (2009). Turizmin disipliner evrimi. Ticaret ve Turizm Eğitim Fakültesi Dergisi, 1(1), 186-206.

Güzeller, C. O., \& Çeliker, N. (2018). Bibliometric analysis of tourism research for the period 2007-2016. Advances in Hospitality and Tourism Research, 6(1), 1-22.

Huang, S. S. (2011). Tourism as the Subject of China's Doctoral Dissertations. Annals of Tourism Research, 38(1), 316-319.

İçöz, O., \& Kozak, N. (1999). Turizm işletmeciliği Dergisi"nin Turizm Literatürüne Katkısı Hakkında Bir inceleme. Anatolia: Turizm Araştırmaları Dergisi, 10, 9-17.

Işık, C., Günlü Küçükaltan, E., Kaygalak Çelebi, S., Çalkın, Ö., Enser, İ., \& Çelik, A. (2019). Turizm ve Girişimcilik Alanında Yapılmış Çalışmaların Bibliyometrik Analizi. Güncel Turizm Araştırmaları Dergisi, 3(1), 119-149.

Jafari, J. (2003). Research and scholarship: the basis of tourism education. Journal of Tourism Studies, 14(1), 6- 
16.

Jafari, J., \& Aaser, D. (1988). Tourism as the subject of doctoral dissertations. Annals of Tourism Research, 15(3), $407-429$.

Jafari, J., \& Ritchie, J. R. (1981). Toward a framework for tourism education. Problems and prospects. Annals of Tourism Research, 8(1), 13-34.

Jovicic, Z. (1988). A plea for tourismological theory and methodology. Revue de Tourisme, 43(3), 2-5.

Karadeniz, E., \& Öcek, C. (2019). Finansal Başarısızlık Riski Taşıyan ile Taşımayan İşletmelerin Finansal Oranlarının Karşılaştırmalı Analizi: Borsa İstanbul Turizm İşletmelerinde Bir Araştırma. Seyahat ve Otel İşletmeciliği Dergisi, 16(2), 191-206. https://doi.org/10.24010/soid.600207

Kervankıran, İ., Sert-Eteman, F., \& Şardağ, A. (2019). Türkiye'de Turizm Coğrafyası Araştırmalarında Disipliner İlişkinin Sosyal A $\breve{g}$ Analizi ile İncelenmesi. Gaziantep University Journal of Social Sciences, 18(3), 938-965.

Kozak, N. (2001). Türkiye' de Turizm Pazarlaması Literatürünün Gelişim Süreci: 1972-1998 Y1llan Arasında Haz1rlanm1s Lisansüstü Tez Çalışmaları Üzerine Biyo-Bibliyografik Bir inceleme. Anatolia: Turizm Araştırmaları Dergisi, 12, 26-33.

Laws, E., \& Scott, N. (2015). Tourism research: building from other disciplines. Tourism Recreation Research, $40(1), 48-58$.

Li, G., Song, H., \& Witt, S. F. (2005). Recent Developments in Econometric Modeling and Forecasting. Journal of Travel Research, 44(1), 82-99.

Liburd, J. J. (2012). Tourism research 2.0. Annals of Tourism Research, 39(2), 883-907.

Ma, J., \& Law, R. (2009). Components of tourism research: Evidence from annals of tourism research. Anatolia, $20(1), 62-74$.

McColl-Kennedy, J. R., Snyder, H., Elg, M., Witell, L., Helkkula, A., Hogan, S. J., \& Anderson, L. (2017). The changing role of the health care customer: review, synthesis and research agenda. Journal of Service Management, 28(1), 2-33.

Meyer-Arendt, K. J., \& Justice, C. (2002). Tourism as the subject of North American doctoral dissertations, 1987-2000. Annals of Tourism Research, 29(4), 1171-1174.

Mohammed, I., Denizci Guillet, B., \& Law, R. (2015). The contributions of economics to hospitality literature: A content analysis of hospitality and tourism journals. International Journal of Hospitality Management, $44,99-110$.

Olcay, A., Karaçil, G., \& Sürme, M. (2018). Helal Turizm Alanının Bibliyometrik Profili. Ĭ̆dır Üniversitesi Sosyal Bilimler Dergisi, 15, 389-408.

Oviedo-García, M. Á. (2016). Tourism research quality: Reviewing and assessing interdisciplinarity. Tourism Management, 52, 586-592.

Özekici, Y. K., \& Ünlüönen, K. (2019). Reflection of acculturation in tourism: A systematic literature review. International Journal of Tourism Anthropology, 7(3-4).

Özel, Ç. H., \& Kozak, N. (2012). Turizm Pazarlaması Alanının Bibliyometrik Profili (2000- 2010) ve Bir Atıf Analizi Çalışması. Türk Kütüphaneciliği, 26(4), 715-733.

Reid, L. J., \& Andereck, K. L. (1989). Statistical Analyses Use In Tourism Research. Journal of Travel Research, 28(2), 21-24.

Ren, C., Pritchard, A., \& Morgan, N. (2010). Constructing tourism research. A critical inquiry. Annals of Tourism Research, 37(4), 885-904.

Şahin, S., \& Acun, A. (2015). Turist Rehberliği Alaninin Bibliyometrik Profili Ulusal Turizm Kongreleri Bildirileri. Balıkesir Üniversitesi Sosyal Bilimler Enstitüsü Dergisi, 18(34), 213-234. 
Saltık, I. A., \& Alimanoğlu, Ç. (2018). Turizmde Örgütsel Davranış Çalışmaları: Adım Üniversiteleri'nde Tamamlanan Lisansüstü Tezler Üzerine Bibliyometrik Bir Araştırma. ICOAEF'18 IV. International Conference on Applied Economics and Finance and Extended with Social Sciences, 392-404. Kuşadas1, Turkey.

Snyder, H. (2019). Literature review as a research methodology: An overview and guidelines. Journal of Business Research, 104, 333-339.

Sökmen, C., \& Özkanlı, O. (2018). Gastronomi Turizmi Alanyazının Gelişimi: Journal of Tourism and Gastronomy Studies Dergisinde Yayımlanan Makaleler Üzerine Bir İnceleme. Journal of Tourism and Gastronomy Studies, 6(2), 99-127.

Song, H., Dwyer, L., Li, G., \& Cao, Z. (2012). Tourism economics research: A review and assessment. Annals of Tourism Research, 39(3), 1653-1682.

Tayfun, A., Küçükergin, F. N., Aysen, E., Eren, A., \& Özekici, Y. K. (2016). Turizm Alanında Yazılan Lisansüstü Tezlere Yönelik Bibliyometrik Bir Analiz. 1(1), 50-69.

Temizkan, S. P., Çiçek, D., \& Özdemir, C. (2015). Sağlık turizmi konusunda yayınlanan makalelerin bibliyometrik profili. International Journal of Human Sciences, 12(2), 394-415.

Tranfield, D., Denyer, D., \& Smart, P. (2003). Towards a Methodology for Developing Evidence-Informed Management Knowledge by Means of Systematic Review. British Journal of Management, 14(3), 207-222.

Tribe, J. (1997). The indiscipline of tourism. Annals of Tourism Research, 24(3), 638-657.

Tribe, J., \& Liburd, J. J. (2016). The tourism knowledge system. Annals of Tourism Research, 57, 44-61.

Ünlüönen, K., \& Özekici, Y. K. (2018). Turizm ve Ödemeler Bilançosu Açısından Akdeniz Çanağında Bulunan Destinasyonlar Üzerine Bir Değerlendirme. Gazi Üniversitesi Turizm Fakültesi Dergisi, 1, 1-33.

Ünlüönen, K., Tayfun, A., \& Kilıçlar, A. (2018). Turizm Ekonomisi (6th ed.). Nobel.

Weiler, B., Moyle, B., \& McLennan, C. L. (2012). Disciplines that influence tourism doctoral research. The United States, Canada, Australia and New Zealand. Annals of Tourism Research, 39(3), 1425-1445.

Wu, B., Xiao, H., Dong, X., Wang, M., \& Xue, L. (2012). Tourism Knowledge Domains: A Keyword Analysis. Asia Pacific Journal of Tourism Research, 17(4), 355-380.

Xiao, H., \& Smith, S. L. J. (2008). Knowledge impact An Appraisal of Tourism Scholarship. Annals of Tourism Research, 35(1), 62-83.

Yeşilyurt, H., \& Koçak, N. (2018). Yerel Halkin Turizm Gelişimine Yönelik Desteğini İnceleyen Makalelerin Bibliyometrik İncelemesi . The Journal of Social Sciences Institute Sosyal Bilimler Enstitüsü Dergisi, 18, 191206.

Yilmaz, I. (2019). Bibliometric Analysis of Bibliometric Studies on Tourism Published in Turkey. Revista Anais Brasileiros de Estudos Turísticos-ABET, 9(1, 2 e 3), 1-9. http://ulakbim.tubitak.gov.tr

Yılmaz, G. (2017a). Restoranlarda Bahşiş İle İlgili Yayınlanan Makalelerin Bibliyometrik Analizi. Seyahat ve Otel İşletmeciliği Dergisi, 14(2), 65-79.

Yılmaz, G. (2017b). Ulusal Turizm Kongrelerinde Gastronomi ve Mutfak Sanatlari Alani ile İlgili Yayinlanan Bildiriler Üzerine Bir Araştirma. Turar Turizm ve Araştırma Dergisi, 6(1), 24-39. 